\title{
Original article (short paper) \\ Physical activity during the early years of life and osteoporosis in adulthood: study among users of the Brazilian National Health System
}

\author{
Bruna Camilo Turi \\ Jamile Sanches Codogno \\ Kyle Robinson Lynch \\ Universidade Estadual Paulista "Júlio de Mesquita Filho," Presidente Prudente, SP, Brasil \\ Universidade Estadual Paulista "Júlio de Mesquita Filho," Rio Claro, SP, Brasil \\ Lia Grego Muniz de Araújo \\ Bruna Locci \\ Universidade Estadual Paulista “Júlio de Mesquita Filho," Rio Claro, SP, Brasil \\ Henrique Luiz Monteiro \\ Universidade Estadual Paulista “Júlio de Mesquita Filho," Presidente Prudente, SP, Brasil \\ Universidade Estadual Paulista "Júlio de Mesquita Filho," Rio Claro, SP, Brasil
}

\begin{abstract}
The objectives of this study were to analyze the association between osteoporosis and current/early physical activity and also to identify whether early sport participation, osteoporosis, age and sex are somehow connected. The study sample included 963 participants. Osteoporosis was diagnosed through medical records. Physical activity in current and the early years of life, age, sex and economic condition were assessed through questionnaires. Abdominal obesity was identified by waist circumference. Results showed that osteoporosis was associated with female sex and higher age. Participants that were active in adulthood had $47 \%$ lower chance of osteoporosis (odds ration [OR] $=$ $0.53[0.30-0.93]$ ). Adults that were active in childhood and adolescence had a lower chance of osteoporosis only in the crude model ( $\mathrm{OR}=0.38[0.22-0.64])$. Women that were inactive in their youth were almost five times more likely to have osteoporosis when compared to men under the same conditions ( $\mathrm{OR}=4.80[2.46-9.37])$. A lack of sports participation in the early years of life seems to be associated with osteoporosis, age and sex.
\end{abstract}

Keywords: osteoporosis, motor activity, childhood, adolescent

\section{Introduction}

In modern society, osteoporosis is a highly prevalent disease that constitutes a public health concern due to its significant impact on health care expenditure ${ }^{1-3}$. Older women are the most affected by this disease, making age and sex critical risk factors ${ }^{1}$. Recently, studies have reported an association between abdominal fat and bone mass density, suggesting that fat deposition in the central region of the body is harmful to bone health ${ }^{4-7}$.

In fact, the natural decrease in bone mass is a common process beginning at age 40 , and it is exacerbated among females mainly due to hormonal, physical, and behavioral characteristics ${ }^{8}$. Regarding behavioral characteristics, women are less physically active than men from an early age ${ }^{9}$ and exercise has been considered an important behavior related to the maintenance of bone health throughout life ${ }^{10}$. From a preventive point-of-view, physical inactivity in the early years of life has been associated as being harmful to health in adulthood, a crucial period of life for the development of several non-communicable diseases ${ }^{9,11}$. Childhood and adolescence are stages of the human development during which the bone mass is determined and, therefore, sports participation during these periods could improve bone mass accrual and, hence, prevent osteoporosis in adulthood ${ }^{12,13}$. In addition, scientific literature indicates that children and adolescents that are physically active tend to remain active throughout adulthood ${ }^{14,15}$.

Conversely, the impact of physical activity in the early years of life on osteoporosis in adulthood is not clear and it is not known if physical activity performed in the early years of life can be associated with osteoporosis, age, and sex. Thus, the purposes of this study were (i) to analyze the association between osteoporosis and current/early physical activity and also (ii) to identify whether early sport participation, osteoporosis, age, and sex are somehow associated.

\section{Methods}

\section{Sample}

The study was carried out from August to December 2010 in , a medium-sized ( $\sim 360,000$ inhabitants $)$ city in 
, the richest state in

Public primary health

care in the city consists of 17 basic health care units. Sample size estimation identified the necessity of interviewing at least 603 participants (osteoporosis prevalence of $21.3 \%{ }^{16}$, power of $80 \%$, alpha error of $5 \%$, and design effect of $50 \%$ ). In order to recruit participants for the study, we selected the largest basic health care unit in each of the five geographical regions of the city. The inclusion criteria were age $50+$ years and at least one year of residence in the area covered by that specific basic health care unit. Lists of all eligible participants who visited the basic health care units within the previous six months were obtained. In total, these lists comprised of 1,915 individuals. We called each of these 1,915 potential participants, inviting them for a baseline assessment between August and December 2010; 963 $(50.3 \%)$ agreed to take part in the study. After data collection and subsequent exclusions, the final sample size was composed of 963 participants of both sexes.

The study was approved by the Ethical Research Committee of

ticipants signed a consent form.

\section{Outcome: Osteoporosis}

The occurrence of osteoporosis was based on physician diagnosis identified through medical records of the participants.

\section{Independent variables: Current physical exercise and sports activities in childhood and adolescence}

Information concerning habitual exercise was assessed using the second section of the questionnaire developed by Baecke and colleagues ${ }^{17}$. We analyzed three aspects of exercise/ sports participation: i) intensity (low, moderate or vigorous), ii) minutes per week ( $<60$ minutes/week; 60-120 minutes/ week; 120-180 minutes/week; 180-240 minutes/week; $>240$ minutes/week), and iii) previous time engaged ( $<1$ month, 1-3 months, 4-6 months, 7-9 months, $>9$ months). Participants were considered sufficiently active when they reported at least 180 minutes of exercise/sports per week (180-240 minutes/ week) on moderate or vigorous intensity over the last four months (4-6 months).

Early sports participation was analyzed using two questions ${ }^{9,14,18}$ : (i) "Outside school, were you ever engaged in any organized/supervised sport activities for at least one year from age 7 to 10 years old?" and (ii) "Outside school, were you ever engaged in any organized/supervised sport activities for at least one year from age 11 to 17 years old?" Adequate levels of reproducibility for early sport participation have been previously reported ${ }^{9}$. For statistical analyses, a variable was created with three possible categories: (i) None: if the participant responded "no" to both questions; (ii) One period: if the participant responded "yes" to just one question; and (iii) Two periods: if the participant responded "yes" to both questions".

\section{Potential confounders}

The following data were used as potential confounders: (i) socio-demographic variables (sex, chronological age [structured as a categorical variable: $<65$ years old and $\geq 65$ years old]); (ii) abdominal obesity, identified by waist circumference measurements (cut-off point for women, 88 $\mathrm{cm}$; men, $102 \mathrm{~cm})^{19,20}$; (iii) economic status, assessed by a specific and previously validated Brazilian questionnaire ${ }^{21}$, which estimates the family income (dichotomized into low or high income).

\section{Statistical analysis}

Categorical data were expressed as rates and 95\%CI. Chi-square test $\left(\chi^{2}\right)$ analyzed the existence of association (Yates' correction was applied in $2 \times 2$ contingency tables) and binary logistic regression (presented as values of odds ratio [OR] and its 95\% confidence intervals [95\% CI]) indicated the magnitude of these associations. Spearman correlation was used to assess the relationship between dependent and independent variables. Statistical procedures were performed using the software BioEstat (release 5.0) and all statistical analyses were set at $\mathrm{p}<0.05$.

\section{Results}

The age of the sample population ranged from 50 to 96 years (mean 64.7 years). Analyzing the occurrence of osteoporosis with risk factors, the crude model showed association between osteoporosis and female sex $(\mathrm{OR}=5.22$ [3.09-8.99]), higher age $(\mathrm{OR}=1.50$ [1.10-2.05]), lower economic status (values for higher economic condition, $\mathrm{OR}=0.61$ [0.38-0.98]), and abdominal obesity $(\mathrm{OR}=1.79[1.23-2.59])$. However, in the multivariate model, only female sex $(\mathrm{OR}=4.32$ [2.32-8.10]) and higher age $(\mathrm{OR}=1.58$ [1.14-2.19]) remained significantly associated with osteoporosis (Table 1).

Regarding current physical activity, adults that were engaged in at least 180 minutes of physical activity per week had $47 \%$ less chance of osteoporosis compared to inactive participants, even after adjustments for sex and age $(\mathrm{OR}=0.53[0.30-0.93])$ (Table 2$)$. Concerning sports participation in the early years of life, adults that were active in childhood and adolescence had a lower likelihood of osteoporosis only in the crude model $(\mathrm{OR}=0.38[0.22-0.64])$ (Table 2). When analyzing the interaction of osteoporosis with physical activity in the early years of life and sex, women that were inactive during their youth were almost five times more likely to have osteoporosis when compared to men under the same conditions, even after adjustments for age and current physical activity $(\mathrm{OR}=4.80$ [2.46-9.37]) (Table 3$)$.

Finally, we found correlations between osteoporosis and age only among adults who were inactive in the early years of life $(r=0.133[0.065$ to 0.199$])$ (Table 4). 
Table 1. Associations between osteoporosis and some independent variables among Brazilian adults $(\mathrm{n}=963)$.

\begin{tabular}{|c|c|c|c|c|}
\hline \multirow{2}{*}{ Independent variables } & \multicolumn{2}{|c|}{$\begin{array}{c}\text { Osteoporosis } \\
\text { Chi-square test }\end{array}$} & \multicolumn{2}{|c|}{$\begin{array}{c}\text { Outcome: Osteoporosis } \\
\text { Binary logistic regression }\end{array}$} \\
\hline & n (\%) & p-value & OR $\left(\mathrm{OR}_{95 \% \mathrm{Cl}}\right)$ & OR $\left(\mathrm{OR}_{95 \% \mathrm{Cl}}\right) *$ \\
\hline Sex & & 0.001 & & \\
\hline Male & $16(6.3)$ & & 1.00 & 1.00 \\
\hline Female & $184(26)$ & & $5.22(3.09-8.99)$ & $5.11(2.93-8.91)$ \\
\hline Age (years) & & 0.013 & & \\
\hline$<65$ & $94(17.7)$ & & 1.00 & 1.00 \\
\hline$\geq 65$ & $106(24.5)$ & & $1.50(1.10-2.05)$ & $1.57(1.14-2.18)$ \\
\hline Economic conditions & & 0.049 & & \\
\hline Low & $176(22)$ & & 1.00 & 1.00 \\
\hline High & $24(14.8)$ & & $0.61(0.38-0.98)$ & $0.76(0.47-1.24)$ \\
\hline Abdominal obesity & & 0.003 & - & \\
\hline No & $42(14.6)$ & & 1.00 & 1.00 \\
\hline Yes & $158(23.4)$ & & $1.79(1.23-2.59)$ & $1.14(0.76-1.70)$ \\
\hline Hosmer and Lemeshow test & & & & \\
\hline Explication of the final model & & & & \\
\hline
\end{tabular}

Notes: $\mathrm{OR}=$ odds ratio; $95 \% \mathrm{CI}=95 \%$ confidence interval; $*$, multivariate model simultaneously adjusted by sex, age, economic condition, and abdominal obesity.

Table 2. Associations between osteoporosis and early/current physical activity among Brazilian adults $(\mathrm{n}=963)$

\begin{tabular}{|c|c|c|c|c|}
\hline \multirow[t]{2}{*}{ Independent variables } & \multicolumn{2}{|c|}{$\begin{array}{c}\text { Osteoporosis } \\
\text { Chi-square test }\end{array}$} & \multicolumn{2}{|c|}{$\begin{array}{l}\text { Outcome: Osteoporosis } \\
\text { Binary logistic regression }\end{array}$} \\
\hline & n (\%) & $p$-value & $\mathrm{OR}\left(\mathrm{OR}_{95 \% \mathrm{CI}}\right)$ & $\mathrm{OR}\left(\mathrm{OR}_{95 \% \mathrm{CI}}\right)^{*}$ \\
\hline \multicolumn{5}{|l|}{ Model-1 } \\
\hline Current physical activity & & 0.001 & & \\
\hline None & $148(23.1)$ & & 1.00 & 1.00 \\
\hline$<180 \mathrm{~min} /$ week & $35(19.7)$ & & $0.81(0.54-1.23)$ & $0.92(0.60-1.41)$ \\
\hline$\geq 180 \mathrm{~min} /$ week & $17(12.1)$ & & $0.45(0.26-0.78)$ & $0.53(0.30-0.92)$ \\
\hline Hosmer and Lemeshow test & & & \multicolumn{2}{|c|}{$p$-value $=0.858$} \\
\hline Explication of the final model & & & \multicolumn{2}{|c|}{$79 \%$} \\
\hline \multicolumn{5}{|l|}{ Model-2 } \\
\hline \multicolumn{5}{|l|}{ Early physical activity } \\
\hline Numerical variable & - & - & $0.38(0.22-0.64)$ & $0.82(0.47-1.42)$ \\
\hline Hosmer and Lemeshow test & & & \multicolumn{2}{|c|}{$p$-value $=0.887$} \\
\hline Explication of the final model & & & & \\
\hline
\end{tabular}

Notes: $\mathrm{OR}=$ odds ratio $; 95 \% \mathrm{CI}=95 \%$ confidence interval; $\mathrm{PA}=$ physical activity; ${ }^{*}$, multivariate model simultaneously adjusted by sex and age.

Table 3. Associations between osteoporosis and sex according to sport participation in childhood and/or adolescence $(n=963)$.

\begin{tabular}{|c|c|c|c|c|}
\hline \multirow{2}{*}{$\begin{array}{l}\text { Sports participation in childhood/ } \\
\text { adolescence }\end{array}$} & \multicolumn{2}{|c|}{$\begin{array}{c}\text { Osteoporosis } \\
\text { Chi-square test } \\
\end{array}$} & \multicolumn{2}{|c|}{$\begin{array}{l}\text { Outcome: Osteoporosis } \\
\text { Binary logistic regression }\end{array}$} \\
\hline & n (\%) & p-value & OR $\left(\mathrm{OR}_{95 \% \mathrm{CI}}\right)^{*}$ & $\mathrm{OR}\left(\mathrm{OR}_{95 \% \mathrm{CI}}\right) * *$ \\
\hline None Period $(n=827)$ & & 0.001 & & \\
\hline \multicolumn{5}{|l|}{ Sex } \\
\hline Male & $10(7.1)$ & & 1.00 & 1.00 \\
\hline Female & $181(26.4)$ & & $4.69(2.41-9.13)$ & $4.80(2.46-9.37)$ \\
\hline Hosmer and Lemeshow test & & & \multicolumn{2}{|c|}{$p$-value $=0.551$} \\
\hline Explication of the final model & & & \multirow{2}{*}{\multicolumn{2}{|c|}{$76.9 \%$}} \\
\hline \multicolumn{3}{|l|}{ Just one/both periods $(n=136)$} & & \\
\hline Sex & & $0.144 \S$ & & \\
\hline Male & $06(5.2)$ & & 1.00 & 1.00 \\
\hline Female & $03(14.3)$ & & $3.02(0.69-13.2)$ & $3.56(0.74-17.1)$ \\
\hline Hosmer and Lemeshow test & & & \multicolumn{2}{|c|}{$p$-value $=0.586$} \\
\hline Explication of the final model & & & & \\
\hline
\end{tabular}

Notes: $\mathrm{OR}=$ odds ratio; $95 \% \mathrm{CI}=95 \%$ confidence interval; *, crude model; $* *$, multivariate model simultaneously adjusted by age and current physical activity; $\S$, Fisher's exact test. 
Table 4. Partial and bivariate correlations between osteoporosis and age according to early sport participation $(\mathrm{n}=963)$.

\begin{tabular}{|c|c|c|c|c|}
\hline $\begin{array}{l}\text { Sport participation in } \\
\text { childhood/adolescence }\end{array}$ & $\begin{array}{c}\text { Model-1 } \\
\text { Pearson }(r)\left(r_{\text {IC95\% }}\right) \\
\text { Chronological age }\end{array}$ & $\begin{array}{c}\text { Model-2 } \\
\text { Pearson }(r)\left(r_{\text {IC95\% }}\right) \\
\text { Chronological age }\end{array}$ & $\begin{array}{c}\text { Model-3 } \\
\text { Pearson }(r)\left(r_{\text {IC95\% }}\right) \\
\text { Chronological age }\end{array}$ & $\begin{array}{c}\text { Model-4 } \\
\text { Pearson }(r)\left(r_{\text {IC95\% }}\right) \\
\text { Chronological age }\end{array}$ \\
\hline \multicolumn{5}{|l|}{ None $(n=827)$} \\
\hline Osteoporosis & $0.116(0.048$ to 0.183$)$ & $0.114(0.046$ to 0.181$)$ & $0.136(0.068$ to 0.202$)$ & $0.133(0.065$ to 0.199$)$ \\
\hline \multicolumn{5}{|l|}{ Just one period $(n=91)$} \\
\hline Osteoporosis & $0.051(-0.157$ to 0.254$)$ & $0.043(-0.164$ to 0.247$)$ & $0.089(-0.119$ to 0.290$)$ & $0.079(-0.129$ to 0.280$)$ \\
\hline \multicolumn{5}{|l|}{ Both Periods $(\mathrm{n}=45)$} \\
\hline Osteoporosis & $-0.053(-0.256$ to 0.155$)$ & $-0.053(-0.256$ to 0.155$)$ & $-0.039(-0.243$ to 0.168$)$ & $-0.039(-0.243$ to 0.168$)$ \\
\hline
\end{tabular}

Notes: $95 \% \mathrm{CI}=95 \%$ confidence interval; Model-1 = crude; Model-2 = controlled by current physical activity; Model-3 = controlled by sex; Model- $4=$ controlled by sex and current physical activity.

\section{Discussion}

In this cross-sectional study with adult users of the Brazilian National Health System, it was possible to identify that the occurrence of osteoporosis was higher in women and older people, mainly when there was absence of sport participation in the early years of life.

Age and sex were significantly associated with osteoporosis, confirming previous position statements of the North American Menopause Society ${ }^{22}$ and the European Society for Clinical and Economic Aspects of Osteoporosis and Osteoarthritis ${ }^{23}$. In fact, aging modifications are associated with decreased lean body mass, increased fat ${ }^{24-26}$ and, in women, due to menopause, a noticeable reduction or absence of hormones also contribute to bone $\operatorname{loss}^{27-29}$.

Higher economic status was also associated with lower occurrence of osteoporosis in our sample. Actually, the role that economic status plays in people's risk for osteoporosis has not been well understood. Trying to explore this association, a recent study conducted in Spain found that lower economic status was linked to higher parathyroid hormone, higher bodyweight, higher body mass index, vitamin D insufficiency, lower body mass index at the lumbar spine, and a higher prevalence of vertebral and non-vertebral fracture ${ }^{30}$. In Brazil, Martini and colleagues $^{31}$ investigated 54,369 individuals in Brazilian capitals and concluded that higher levels of education provided protection for the occurrence of osteoporosis. In another Brazilian study with women, $73.3 \%$ reported having osteoporosis and/or osteopenia and were considered illiterate ${ }^{32}$.

Concerning the association between osteoporosis and abdominal obesity, previous studies reported negative relationships between measurements of abdominal obesity and lower bone mass ${ }^{33,34}$. The pathways by which abdominal obesity affects bone tissue are not completely understood yet, but involve the action of inflammatory markers produced by adipose tissues, which affect the osteoblasts/osteoclasts ratio in the bone matrix ${ }^{35}$, leading to lower bone mass.

In regards to lifestyle factors, current physical activity was associated with lower occurrence of osteoporosis, findings similar to those of other studies ${ }^{16,36}$. When analyzing physical activity performed during the early years of life, our results indicated that women who were inactive in childhood and adolescence were almost five times more likely to have osteoporosis when compared to men under the same conditions, even after adjustments for age and current physical activity. These results indicate that lack of sports participation in the early years of life is associated with osteoporosis, age, and sex. According to Lima and colleagues ${ }^{12}$, sport activity performed during childhood/adolescence was related to higher bone mineral density, even after adjustments for current physical activity, obesity and other variables harmful to bone formation. These findings show that current physical activity could act as a support factor in reducing bone loss caused by the aging process, but, in fact, bone mass is determined during childhood/adolescence. From this perspective, this finding highlights the importance of sports participation during childhood/adolescence in preventing outcomes such as osteoporosis in adulthood ${ }^{12}$.

However, limitations should be recognized: the cross-sectional design constitutes the main limitation due to non-possibility of causality statements. Therefore, prospective studies analyzing this issue in participants of the public healthcare system are necessary. Moreover, the absence of measures of bone mineral content, density, and methylation rates should be recognized as significant limitations. We also recognize the lack of information about intensity of sports activities in childhood and adolescence.

In summary, we conclude, in this representative sample of adult users of the Brazilian National Health System, that lack of sports participation in the early years of life is associated with osteoporosis, age, and sex. ${ }^{6}$

\section{References}

1. National Osteoporosis Foundation. Strong voices for strong bones. Washington, DC, 2008. Retrieved June 10, 2010 from: http://nof. org/files/nof/public/content/file/63/upload/49.pdf.

2. Codogno JC, Freitas Junior IF, Fernandes RA, Monteiro HL. Behavioral and biological correlates of medicine use in type 2 diabetic patients attended by Brazilian public healthcare system. Rev Bras Cineamtropom Desempenho Hum. 2013; 15(1):82-88. 
3. Svedbom A, Ivergård M, Hernlund E, Rizzoli R, Kanis JA. Epidemiology and economic burden of osteoporosis in Switzerland. Arch Osteoporos. 2014;9:187.

4. Liu YH, Xu Y, Wen YB, Guan K, Ling WH, He L, et al. Association of weight-adjusted body fat and fat distribution with bone mineral density in middle-aged Chinese adults: a crosssectional study. PLoS One. 2013; 8(5): e63339.

5. Katzmarzyk PT, Barreira TV, Harrington DM, Staiano AE, Heymsfield SB, Gimble JM. Relationship between abdominal fat and bone mineral density in white and African American adults. Bone. 2012; 50(2): 576-579.

6. Bhupathiraju SN, Dawson-Hughes B, Hannan MT, Lichtenstein $\mathrm{AH}$, Tucker KL. Centrally located body fat is associated with lower bone mineral density in older Puerto Rican adults. Am J Clin Nutr. 2011; 94(4):1063-70.

7. Zillikens MC, Uitterlinden AG, van Leeuwen JP, Berends AL, Henneman P, van Dijk KW, et al. The role of body mass index, insulin, and adiponectin in the relation between fat distribution and bone mineral density. Calcif Tissue Int. 2010; 86(2):116-25.

8. Rizzoli R, Bonjour JP, Ferrari SL. Osteoporosis, genetics and hormones. J Mol Endocrinol. 2001; 26(2):79-94.

9. Fernandes RA, Zanesco A. Early physical activity promotes lower prevalence of chronic diseases in adulthood. Hypertens Res. 2010; 33(9):926-31.

10. Haskell WL, Lee IM, Pate RR, Powell KE, Blair SN, Franklin BA, et al. Physical activity and public health: updated recommendation for adults from the American College of Sports Medicine and the American Heart Association. Med Sci Sports Exerc. 2007; 39(8):1423-34.

11. Sociedade Brasileira de Pediatria. Departamento Científico de Nutrologia. Atividade física na infância e na adolescência: guia prático para o pediatra, 2008. Retrieved March 11, 2015 from http://www.sbp.com.br/pdfs/9667d-DOC-CIENT-AtivFisica.pdf.

12. Lima MC, Cayres SU, Agostinete RR, Ito IH, Fernandes RA. Estabilidade da prática esportiva durante a infância/adolescência e densidade mineral óssea na idade adulta. Rev Bras Ativ Fis Saúde. 2013; 18(4):445-452.

13. Silva CC, Teixeira AS, Goldberg TBL. O esporte e suas implicações na saúde óssea de atletas adolescentes. Rev Bras Med Esporte. 2003; 9(6):426-431.

14. Fernandes RA, Sponton $\mathrm{CHG}$, Zanesco A. Atividade física na infância e adolescência promove efeitos benéficos na saúde de adultos. Rev SOCERJ. 2009; 22(6):365-372.

15. Azevedo MR, Araújo CL, Cozzensa da Silva M, Hallal PC. Tracking of physical activity from adolescence to adulthood: a population-based study. Rev Saúde Pública. 2007; 41(1):69-75.

16. Baccaro LF, de Souza Santos Machado V, Costa-Paiva L, Sousa MH, Osis MJ, Pinto-Neto AM. Factors associated with osteoporosis in Brazilian women: a population-based household survey. Arch Osteoporos. 2013; 8:138.

17. Baecke JAH, Burema J, Frijters JER. A short questionnaire for the measurement of habitual physical activity in epidemiological studies. Am J Clin Nutr. 1982; 36(5):936-942.

18. Fernandes RA, Christofaro DG, Casonatto J, Codogno JS, Rodrigues EQ, Cardoso ML, et al. Prevalence of dyslipidemia in individuals physically active during childhood, adolescence and adult age. Arq Bras Cardiol. 2011; 97(4):317-323.
19. Peixoto MRG, Benicio MHD, Latorre MRDO, Jardim PCBV. Circunferência da cintura e índice de massa corporal como preditores da hipertensão arterial. Arq Bras Cardiol. 2006; 87(4):462-470.

20. Lohman TG, Roche AF, Mertorell R. Anthropometric Standardization Reference Manual. Champaign: Human Kinectics Books; 1988.

21. Associação Brasileira de Empresas de Pesquisa. Levantamento sócioeconômico-2000-IBOPE. Retrieved June 3, 2011 from: http://www.abep.org.br.

22. The North American Menopause Society. Management of osteoporosis in postmenopausal women: 2010 position statement of The North American Menopause Society. Menopause. 2010; 17(1):25-54; quiz 55-56.

23. Kanis JA, McCloskey EV, Johansson H, Cooper C, Rizzoli R, Reginster JY, et al. European guidance for the diagnosis and management of osteoporosis in postmenopausal women. Osteoporosis Int. 2013; 24(1):23-57.Gadelha AB, Dutra MT, Oliveira RJ, Safons MP, Lima RM. Associação entre força, sarcopenia e obesidade sarcopenica com o desempenho funcional de idosas. Motricidade. 2014; 10(3):31-39.

24. Mastroeni MF, Mastroeni SSBS, Erzinger GS, Marucci MFN. Antropometria de idosos residentes no município de Joinville-SC, Brasil. Rev Bras Geriatr Gerontol. 2010; 13(1):29-40.

25. Menezes TN, Marucci MF. Antropometria de idosos residentes em instituições geriátricas. Rev Saúde Pública. 2007; 39(2):169-75.

26. Veiga Silva AC, Rosa MI, Fernandes B, Lumertz S, Diniz RM, Damiani MER. Fatores associados à osteopenia e osteoporose em mulheres submetidas à densitometria óssea. Rev Bras Reumatol. 2015; 55(3):223-228.

27. Ministério da Saúde. Secretaria de Atenção à Saúde. Portaria $N^{\circ} 224$, de 26 de Março de 2014 Aprova o Protocolo Clínico e Diretrizes Terapêuticas da Osteoporose, 2014. Retrieved March 15, 2015 from: ftp://ftp.saude.sp.gov.br/ftpsessp/bibliote/informe_eletronico/2014/ iels.mar.14/Iels59/U_PT-MS-SAS-224_260314.pdf

28. Maartens LW, Leusink GL, Knottnerus JA, Smeets CG, Pop VJ. Climacteric complaints in the community. Fam Pract. 2001; 18(2):189-194.

29. Navarro Mdel C, Saavedra P, Jódar E, Gómez de Tejada MJ, Mirallave S, Sosa M. Osteoporosis and metabolic syndrome according to socio-economic status; contribution of PTH, Vitamin D and body weight: The Canarian Osteoporosis Poverty Study (COPS). Clin Endocrinol. 2013; 78(5):681-6.

30. Martini LA, Moura EC, Santos LC, Malta DC, Pinheiro MM. Prevalência de diagnóstico auto-referido de osteoporose, Brasil, 2006. Rev Saúde Pública. 2009; 43(Supl 2):107-116.

31. Schiavo GMN. Perfil do consumo nutricional de pacientes com massa óssea diminuída. Rev Ciênc Ext. 2014; 10(2):7-18.

32. Chung W, Lee J, Ryu OH. Is the negative relationship between obesity and bone mineral content greater for older women? J Bone Miner Metab 2014; 32(5):505-13.

33. Gimble JM, Robinson CE, Wu X, Kelly KA. The function of adipocytes in the bone marrow stroma: an update. Bone. 1996; 19(5):421-428.

34. Cao JJ. Effects of obesity on bone metabolism. J Orthop Surg Res. 2011;6:30. 
35. Pinheiro MM, Reis Neto ET, Machado FS, Omura F, Yang JHK, Szejnfeld J, Szejnfeld VL. Risk factors for osteoporotic fractures and low bone density in pre and postmenopausal women. Rev Saúde Pública. 2010; 44(3):479-485.

\section{Corresponding author}

Bruna Camilo Turi.

Address: 305 Roberto Simonsen St. 19060-900. President Prudente, SP, Brazil.

Email: brunaturi@hotmail.com
Manuscript received on April 29, 2016

Manuscript accepted on August 10, 2016

(c) (i)

Motriz. The Journal of Physical Education. UNESP. Rio Claro, SP, Brazil - eISSN: 1980-6574 - under a license Creative Commons - Version 3.0 